\title{
O Conceito de "Vida Humana" e as Novas Biotecnologias da Reprodução: analisando uma rede de controvérsias
}

\section{The concept of "human life" and reproduction new biotechnologies: analyzing a net of controversies}

\author{
Júlio Cesar de Almeida Nobre ${ }^{1}$ \\ Mateus de Oliveira vale ${ }^{2}$ \\ Eder Frossard de Andrade ${ }^{2}$ \\ Rafael Lima Ribeiro ${ }^{3}$
}

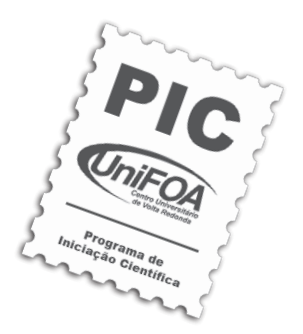

\section{Artigo \\ Original}

Original

Paper

Palavras-chaves:

Resumo

Redes

Biotecnologias da Reprodução

Cotrovérsias

Vida Humana

\section{Abstract}

Com o advento das novas biotecnologias de reprodução, passamos a conviver com intensas turbulências no que se refere ao conceito de vida humana. Tais tecnologias parecem produzir um mundo bastante vertiginoso para olhares habituados a conceber a representação de humano como sendo uma fronteira natural. Essas perspectivas parecem ancoradas em uma concepção de tecnociência e humanidade como polaridades estanques. Na atualidade, nos deparamos com uma constante mistura entre aquilo que entendemos por humanidade e não-humanidade. Questões como a infertilidade, a reprodução medicamente assistida, a clonagem e principalmente as pesquisas com células embrionárias apontam para a reprodução e condição humanas cada vez mais imbricadas com o artifício. No presente trabalho, abordamos tal cenário a partir do pensamento de Bruno Latour. Em sua teoria das Redes Sociotécnicas, todo e qualquer fato sólido depende de um processo bastante conectivo, onde humanos e não-humanos o colocam em circulação. O foco se volta para a potência de intensas traduções. Com o conceito "vida humana" não é diferente. A partir de lentes híbridas nos debruçamos sobre uma atualidade de intensa controvérsia, onde a natureza do que chamamos humano parece estar em jogo em meio a uma diversidade de mediações. Com o intuito de estudarmos a dinâmica conectiva de tais controvérsias a envolver as novas biotecnologias da reprodução, objetivamos as diferentes traduções da vida humana feitas por múltiplos actantes no controvertido tema. Analisamos alguns periódicos de grande visibilidade e influência no Brasil. Nosso recorte temporal foi limitado entre 2007 e 2008 devido ao grande dinamismo na área de discussão.

With the arrival of new biotechnologies of reproduction, we started to live with intense turbulences in what is concerned to the human life concept. Such technologies seem to produce a very vertiginous world for eyes which are used to understand the human representation as a natural frontier. Those perspectives seem to be anchored in a conception of techno-science and humanity as impassable polarities. Nowadays we face a constant mixture between those things we understand as humanity and not-humanity. Questions like infertility, medically assisted reproduction, cloning and principally the researches using embryonic cells point to a reproduction and human conditions more and more linked to the artifice.

In the present work we approach such scenery from Bruno Latour thinking. In his theory of Socialtechnic Nets, every solid fact depends on a very
Key words:

Nets

Reproduction Biotechnologies

Controversies

Human Life

\footnotetext{
Mestre - Psicossociologia - UniFOA

2 Acadêmicos - Serviço Social - UniFOA

${ }^{3}$ Acadêmico - Administração - UniFOA
} 
connective process, in which human and non-human put in circulation. The focus is on the potency of intense translations. With the "human life" conception it is not different.

Starting from hybrid lens, we looked to a actuality of immense controversy, where the nature of what we call human seems to be in game inside a diversity of mediations. With the intention of studying the connective dynamic of such controversies involving new reproduction biotechnologies, we aim the different translations of human life made by multiple agents in the controverted theme. We analyzed some periodic publications, with a large visibility and influence in Brazil. Our time frame was limited between 2007 and 2008 because of the great dynamism in the area of discussion.

\section{Introdução}

$\mathrm{Na}$ atualidade, vivemos em um turbilhão de conflitos em diversos terrenos, de possibilidades diversas que parecem inviabilizar a possibilidade de uma sólida unidade. Muitos são os autores que apontam para o convívio constante com certa dose de tensão a todo o momento. É a partir de tal cenário atual que o presente artigo é desenvolvido. Pretendemos introduzir a participação crucial das novas biotecnologias da reprodução neste quadro de instabilidades. O atual quadro biotecnológico parece encontrar na metáfora do ciborgue (Haraway, 2000), um símbolo. Os ciborgues emblematizam, em sua simples existência, uma hibridação entre tecnologia e natureza. São seres da parcialidade - nenhuma totalidade - que conectam essas duas instâncias - entendidas como sólida dicotomia. Essa metáfora parece indicar a inexistência de um puro humano, assim como a de um puro inumano/máquina. Ele é da ordem do fronteiriço.

A natureza, nas mãos das atuais biotecnologias, aponta para a possibilidade de ser modificada e redefinida constantemente. Nesse ambiente biotecnológico, nosso foco de questionamento reside no conceito de "vida humana" diante das novas biotecnologias de reprodução. Tal conceito parece-nos estar ancorado, comumente, em uma concepção em que tecnociência e humanidade configurariam polaridades estanques. De um lado, a artificialidade das novas tecnologias e de outro, a natureza humana. O presente artigo, portanto, diferentemente de tal concepção, tem por foco os elos que unem tais campos. Busca-se uma rede em ação, onde os diversos agentes humanos e não-humanos a constroem em uma instantaneidade. Nenhum fora atemporal. Por intermédio de uma breve análise da controvérsia, que cartografe alguns dos diversos nós destas redes imanentes, focalizaremos o conceito de vida humana a se produzir em múltiplas traduções.

Assim sendo, iniciaremos a presente análise por uma contextualização das biotecnologias da reprodução na atualidade e as constantes tensões e traduções que invadem nosso tempo - no que se refere ao conceito de vida humana. Veremos diferentes argumentos, alguns bastante ufanistas em relação às novas possibilidades biotecnológicas e outros nem tanto, a favor de forte regulação ou até mesmo exclusão de determinadas técnicas. Em seguida, iremos apresentar o modelo das redes sociotécnicas, de Bruno Latour, como uma possibilidade de entendimento diferenciado do tema. Em tal modelo, não existe uma solidez a priori na tecnologia ou na humanidade. Pensaremos tais pólos como imbricados e teremos por foco as conexões, as traduções, os híbridos. Encerraremos nossa reflexão com uma breve análise da controvérsia acerca do conceito de vida humana, cartografando a mesma em periódicos de grande relevância no cenário contemporâneo.

\section{As Novas Biotecnologias da Reprodução: entre o paraíso e a decadência}

As novas biotecnologias da reprodução têm sido sinônimo, na atualidade, de tecnologia de ponta a serviço de uma melhor qualidade de vida - saúde - para os seres humanos. Reprodução in Vitro, testes de DNA, pesquisas com células-tronco e clonagem são termos que emergem em nosso cotidiano com uma freqüência cada vez maior e povoam as páginas das revistas e jornais 
de maior circulação. Se, por um lado, tais tecnologias representam promessa de melhoria na condição humana, por outro, parecem trazer o temor de um excesso de artifício a permear o que entendemos por natureza humana. Eis o paradoxo: quanto mais é buscada uma purificação, um melhor ordenamento do humano, mais essa humanidade parece escorrer entre os dedos e se instabilizar.

A atualidade parece marcada pelo signo do artifício - e pela ambivalência entre ufanismo e terror - diante deste. Discursos acerca da importância de uma bioética a nortear nossas ações nesse campo - característica de nossos dias - acabam por revelar o sentimento de desamparo que a humanidade vive diante do tecnológico. "Criador é dominado pela criatura" - o Dr. Frankenstein seria um emblema para essa condição atual. Proteger o humano de uma técnica cega e desumana parece ser a palavra de ordem do momento. Por outro lado, em defesa da tecnologia, vemos toda uma constelação de discursos que apresentam a técnica como garantia de progresso por si só. Um instrumental iluminado a serviço da ascensão dos humanos. Técnica e humano, dois campos distintos e dispostos em oposição, dois sólidos que não podem se misturar. Tal perspectiva parece permear as mais diversas óticas atuais.

As novas biotecnologias da reprodução compõem um quadro - por demais complexo, a envolver várias questões de diversas ordens e dimensões - que deve ser tratado com o maior cuidado possível. Dentro de tal tema, muitos são os assuntos que têm possibilitado importantes reflexões - e controvérsias - tais como: a questão da infertilidade, da anticoncepção, da reprodução natural, da reprodução medicamente assistida, das pesquisas com células embrionárias, da clonagem, entre outros. Essas controvérsias parecem revelar uma atualidade de intensa artificialização de processos reprodutivos até então considerados como naturais. A infertilidade, por exemplo, foi tratada por muito tempo como sendo uma manifestação da vontade divina, não sendo permitida a interferência dos humanos. Atualmente, passa a ser entendida como um problema de saúde. Isso se deve ao desenvolvimento de tecnologias - como a reprodução in vitro - que prometem uma superação de tais quadros - entendidos como deficiências humanas. A tecnologia parece produzir um humano imperfeito, passível de ser modelado e conduzido à melhoria.

É bem verdade que a infertilidade costuma causar um enorme sofrimento para aquele que tem que conviver com ela e, até mesmo, quadros de intensa depressão. Quando se fala em reprodução humana, tem se falado conjuntamente em liberdade de escolha sobre a procriação (Braz, 2005). Com o crescimento do movimento feminista e do avanço das técnicas - e da produção de novos medicamentos - as mulheres começam a decidir quando e quantos filhos vão ter. Nesse contexto, passam a desejar uma maior participação no mercado de trabalho - muitas vezes deixando a maternidade em um segundo plano. Isso acaba por levar a uma postergação e possibilidade de complicações - na gravidez. Tais complicações acabam por ser contornadas via tecnologia. Estamos diante de uma intensa medicamentalização da reprodução. $\mathrm{O}$ artifício acaba por construir instabilidades que são respondidas com mais artifício. Este termina por se misturar intensamente com aquilo que entendemos, até então, por reprodução natural.

No Brasil, por exemplo, tal argumento fica bastante claro quando vemos que o acesso a tais biotecnologias da reprodução humana parece ser bastante desigual. Vejamos por que: quando falamos de tecnologias mais simples, como a anticoncepção, a falta de eqüidade acaba por resultar em uma ausência de escolhas acerca do melhor método anticoncepcional a ser utilizado - seja pela desinformação ou pela simples ausência de serviços de saúde. Diante dessa situação, podemos ver diferentes discursos. Algumas vezes encontramos uma retórica sobre os benefícios de não se investir na infertilidade de tais indivíduos como política de enfrentamento da miséria. Mais ainda, alguns argumentos acabam por cogitar a possibilidade do aborto como prevenção à "marginalidade". Outros discursos, por sua vez, apontam que o combate da miséria só encontrará eficácia se a população, de um modo geral, tiver acesso mais justo e eqüitativo aos serviços de saúde com qualidade. A reivindicação, nesse caso, seria uma universalização dos direitos ao acesso às biotecnologias da reprodução humana para a população dita excluída. Parece que, de um modo ou de outro, o artifício permeia nossa atualidade. Problemas sociais, 
políticos, individuais parecem se misturar intensamente com a tecnologia. A solução? Mais tecnologia, maior acesso a esta. . Mais uma vez a atualidade tecnológica parece produzir um humano imperfeito e passível de ser conduzido a melhoria pela mão da própria tecnologia ${ }^{1}$. Vemos tecnologia levando a mais tecnologia. Parece que, quando se busca uma melhoria na condição dos humanos - uma purificação destes - novas portas, novas configurações - e renovados problemas - se atualizam.

Miguel Kottow (2005) aponta que tal artifício a se misturar com a vida humana parece não ter produzido maiores atritos no que tange ao tema da fecundação assistida. Nessa área, não existem grandes protestos, devido a não haver uma abundância de tecnologia invasiva da condição humana e, portanto, tal tecnologia acaba por ser entendida como apenas apoiando os processos naturais. Teríamos, aqui, o entendimento de tal situação apenas como um processo de purificação do humano. A crítica, segundo o autor, tem se concentrado mais na produção de embriões do que na fecundação e na sua implantação em um útero. Produz-se um excesso destes embriões que acabam sendo congelados, descartados ou mesmo fornecidos como material biológico para fins de investigação. Temos aqui uma vertigem: seria o embrião um humano ou não? Nesse ponto, a controvérsia é enorme: há os que já consideram o embrião um ser humano e, portanto, consideram tais atitudes inaceitáveis; e há os que afirmam que tal material biológico é apenas um pré-embrião, não sendo homólogo aos seres humanos. Tal turbulência é traduzida de diversos modos.

Para a bioética laica existem quatro concepções diferentes que tematizam o início da vida humana (Kotow, 2005). Na doutrina eclesiástica, condena-se a suspensão voluntária da gravidez, proibindo a anticoncepção artificial ou qualquer intervenção no processo reprodutivo considerado como natural - e por conseqüência, toda relação sexual passou a ser considerada como potencial início da vida. O ponto exato de tal início é mesmo, sem dúvida, um dos temas que mais geram polêmica nas discussões sobre bioética. Por essa razão, existe um intenso debate bioético buscando decidir um estatuto moral e uma conduta ética diante das novas biotecnologias da reprodução humana. Tal debate passa por um reconhecimento da existência humana e sobre os critérios de validação desse reconhecimento. A primeira tentativa de se estabelecer um ponto exato para o início da vida humana encontra-se na visão concepcional, que toma por referência a união do óvulo com o espermatozóide. Tal critério parece ter seu sentido esvaziado quando se associa a pessoa humana com uma racionalidade essencial. Em função de tal associação razão-humano, a perspectiva concepcional reconhece o aparecimento da humanidade desde o momento da fecundação - sem levar em consideração a modificação radical que se processa ao longo do tempo - a tal ponto que se tornará bastante difícil enxergar o zigoto em uma pessoa adulta. Aborda-se, aqui, a vida humana não se considerando como relevantes todos os processos de desenvolvimento, maturação, diversificação e transformação para a determinação da humanidade.

A segunda abordagem se refere à visão evolutiva. Esta propõe que o início da vida humana se dá no $14 .^{\circ}$ dia de gestação, já que é nesse período que o embrião se implanta e se afirma com probabilidades de viabilidade. Entretanto, essa visão é considerada por muitos como dispensável, por não ter um reconhecimento generalizado.

Existem muitas perspectivas que situam o começo da vida humana em etapas posteriores. A terceira concepção para o início da vida humana é uma delas. A visão social traz para a discussão a idéia de que os humanos evoluem de acordo com os símbolos culturais elaborados no seio da sociedade. Dessa forma, tal corrente considera que as células-tronco não têm um estatuto moral próprio, por serem apenas células totipotentes e não indivíduos humanos. Tudo o que a pessoa vem a ser é considerado como produto de influências externas. Tal abordagem parece menosprezar uma espécie de "superfície onde as circunstâncias se realizam”. Não existem considerações sobre alguma faceta do ser que não seja simplesmente cultura. Natureza/corpo

\footnotetext{
${ }^{1}$ Outro cenário tecnológico importante a ser citado diz respeito aos testes genéticos. Depois que o DNA - os Genes - fora "desnudado" através do Projeto Genoma Humano, vemos um forte discurso sobre a possibilidade de se adiar o início das doenças e o aperfeiçoamento de drogas para combatê-las e/ou tratá-las. O discurso do DNA entra em cena e extrapola os ambientes "técnicos". A genética passa a visitar os holofotes. Polêmicas sobre paternidade acabam por freqüentar a mídia e colocar a genética como um importante mediador, até mesmo, em questões de filiação
} 
de um lado, cultura do outro.

A quarta e última concepção de vida humana é dada pela visão relacional. Nesta abordagem, o feto é reconhecido como humano quando estabelece uma relação de empatia com outro ser, ou seja, quando a mulher se descobre grávida e aceita, ou não, a maternidade. Dessa forma, a visão relacional não opina sobre a ontogênese, pois credita à mulher a decisão sobre o momento do rec'onhecimento de um novo ser. Nesse sentido, o seu foco não é determinado pelo biológico. A perspectiva relacional aponta para o reconhecimento de uma pessoa humana propriamente no estabelecimento de uma relação com esta. É a humanidade sendo produzida no campo das relações - sempre humanas.

Podemos perceber que diferentes são os focos a abordar o conceito de vida humana. Diante das diferentes produções mais recentes da biotecnologia a reprodução, a humanidade parece ter seu fundamento bastante discutido na atualidade. Temos visto, nessas perspectivas, uma busca do justo foco, do ponto exato onde residiria aquilo que poderíamos conceber como humanidade em meio a tantas vertigens e instabilidades. Por outro lado, Rabinow, em seu artigo intitulado "Artificialidade e iluminismo: da sociobiologia a biossociabilidade", aborda as imbricações dessas tecnologias com o social por intermédio de uma nova genética que

(...) deixará de ser uma metáfora biológica para a sociedade moderna e se tornará uma rede de circulação de termos de identidade e lugares de restrição, em torno da qual e através da qual surgirá um tipo verdadeiramente novo de autoprodução: (...) biossociabilidade. (Rabinow, 2002: 143)

O autor prevê o fim da genéticametáfora, inserida na sociobiologia, na qual os preceitos biológicos abordados são de que a cultura é construída por uma metáfora da natureza. Agora, a genética se tornaria um fator de mudança do natural, ou seja, a natureza é modelada pela cultura compreendida como prática. A essa atualidade, o autor dá o conceito de biossociabilidade. Encontramos uma medicina que não tem mais - gradativamente - o viés do diagnóstico e da normalização, mas o da prevenção. Exames genéticos passarão a constatar a probabilidade da futura existência de uma determinada doença e, por conseguinte, a maximização da melhoria do corpo por meio da minimização dos ditos genes ruins. A partir disso "haveria a formação de novas identidades de práticas individuais e grupais" (Rabinow, 2002). Surgirão grupos de possíveis portadores de uma doença específica que se reunirão em torno dessa característica comum para discutir suas histórias de vida, formas de prevenção e novas tecnologias de prevenção. Estes passarão a buscar profissionais especializados em suas particularidades que sejam capazes de monitorá-los.

Na biossociabilidade a natureza será modelada
na cultura compreendida como prática; ela será
conhecida e refeita através da técnica, a natureza
finalmente se tornará artificial, exatamente como a
cultura se tornou natural. (Rabinow, 2002: 144)

A humanidade parece estar em um ponto bastante radical, onde uma ótica que separe o que é o naturalmente humano do artifício parece ser bastante problemático. Testemunhamos um momento em que as concepções sobre a vida humana são desconstruídas pela tecnociência, e antigas bases parecem começar a sair de cena: O que é humano? O que não é? E por quê? Questões...

$\mathrm{O}$ trabalho da médica Catherine Waldby é um exemplo disso. Enquanto outros setores da tecnociência focalizam nos trabalhos com o genoma humano, Waldby traduziu o corpo humano para uma substância digital. Nesse trabalho, intitulado como o Projeto do Homem Visível, o que antes era tão sólido como o funcionamento básico do corpo humano, agora, é colocado em xeque. Tal projeto consiste no corpo humano visível por inteiro, digitalizado e disponibilizado na web. O objetivo é a visibilidade do corpo ao olhar clínico. Porém,

(...) para transformar seus corpos em dados digitais foi preciso todo um procedimento que anulou literalmente a sua massa (...) cadáveres transfiguramse numa série de imagens planas acessadas uma a uma para visualização, mas também manipuladas de modo ilimitado (Garcia dos Santos, 2003: 266).

O humano não é concebido aqui como uma representação, mas sim como uma matéria bruta para a modelagem. Saímos do representacional para o operacional. O humano passa a ser produzido como orgânico e técnico em um mesmo fôlego. Estas produções se cruzam com as novas pesquisas de organismos cibernéticos, trazendo ainda mais dificuldades no sentido de fixar um ordenamento único natural ou social - para a vida humana. Parece 
que, partindo dessa constatação, a indústria do cinema acaba por explorar intensamente tanto o tema do cyborg como de assuntos afins. Roteiros que mostram máquinas com sentimentos humanos, vidas prolongadas pela utilização de órgãos vitais artificiais - ou mesmo as intempéries da inteligência artificial - parecem começar a delinear os conceitos de uma nova existência - humana (?). A ciência conversa com utopias e negocia a produção da realidade.

Segundo Donna Haraway (2000), podemos naturalmente aceitar organismos cibernéticos como evolução natural. A tradução do mundo em informação digital e dos seres vivos em genética atinge diretamente o aperfeiçoamento das espécies, reformulando até mesmo os conceitos sobre evolução e a criação da vida. Haraway formula a construção de um pós-humano, onde o homem deixa de ter um fundamento e torna-se uma nova espécie, híbrida de humano e tecnologia.

Katherine Hayles (in Garcia dos Santos, 2003), por sua vez, preocupa-se em definir o que seria esse pós-humano. Cria uma visão em que o corpo é a apenas a prótese original que aprendemos a manipular e que, a extensão do corpo com outras próteses ou a substituição de membros é a continuação de um processo que começou bem antes mesmo de nascermos. Segundo Hayles, no póshumano não há demarcações de limites entre a existência corporal e a simulação de um computador, entre mecanismos cibernéticos e organismos biológicos, a programação do robô e as finalidades humanas.

Tais autores parecem apontar que a raça humana se depara com questões que nunca antes imaginou que seriam possíveis. Será mesmo que não há limites? Será que nos tornamos neste século o que era impossível aos olhos das primeiras civilizações? Diante de exemplos como a inseminação artificial in vitro, a clonagem e as células-tronco, é impossível que a imaginação não viaje diante de tais argumentos ${ }^{2}$ e ocasione sentimentos entre o temor e a ufania dos poderes da técnica.

\subsection{O Conceito de Vida Humana e o} Cristianismo

Asnovasbiotecnologias dareprodução e sua instabilização do que entendemos por humanidade tem um forte impacto nos posicionamentos religiosos. O conceito de vida humana sempre foi um termo bastante caro às igrejas cristãs. Não é por menos, pois tal vida tem sido valorizada por todos os segmentos do cristianismo. A referência bíblica quanto à origem divina da vida - vir de Deus - é base de fé para milhões de fiéis em todo o mundo. Quer católicos tradicionais ou carismáticos, evangélicos mais austeros ou reformadores, todos concordam com a concepção de que a origem da vida surgiu do fôlego que Deus soprou nas narinas do homem formado do pó da terra. Apesar dessas convergências, as discordâncias em temas como pesquisas com células embrionárias são bem grandes.

A visão da igreja católica, através do Concílio Vaticano II, relata, com uma página de dramática atualidade, a utilização de embriões recém-formados na utilização de estudos em benefício da saúde. Deplorou fortemente a inovação científica como múltiplos crimes e atentados contra a vida humana. O Papa João Paulo II, em seu artigo Evangelium Vitae, aponta que:

Tudo quanto se opõe à vida, como seja toda a espécie de homicídio, genocídio, aborto, eutanásia e suicídio voluntário; tudo o que viola a integridade da pessoa humana, como as mutilações, os tormentos corporais e mentais e as tentativas para violentar as próprias consciências; tudo quanto ofende a dignidade da pessoa humana, como as condições de vida infrahumanas, as prisões arbitrárias, as deportações, a escravidão, a prostituição, o comércio de mulheres e jovens; e também as condições degradantes de trabalho, em que os operários são tratados como meros instrumentos de lucro e não como pessoas livres e responsáveis. Todas estas coisas e outras semelhantes são infamantes; ao mesmo tempo em que corrompem a civilização humana, desonram mais aqueles que assim procedem, do que os que padecem injustamente; e ofendem gravemente a honra devida ao Criador (Cf. Encíclica Evangelium Vitae, 3)

Uma importante contradição é que, muitos praticantes do catolicismo manifestam suas opiniões pessoais sem levar em consideração a direção dos líderes da igreja. Uma coisa é a perspectiva do clero, outra é a

\footnotetext{
${ }^{2}$ A releitura de Foucault por Deleuze lança questões ainda mais desconstrutivas: a morte não seria o ponto final da vida. Deleuze confronta as forças conhecidas de Deus com as forças desconhecidas pelo próprio homem. Ele vê o esboço de uma nova relação de forças e a constituição de um novo humano: a forma Além-do-Homem. Deleuze acredita que o ser humano pode liberar nele mesmo a vida. Sendo isso possível, a morte nada mais seria do que uma deficiência do homem em não aprender como renovar e prolongar sua energia vital, justificada pela parte da capacidade cerebral que ainda é desconhecida.
} 
visão de quem vive a vida cotidiana. Mesmo com a proibição do aborto, milhares de mulheres, todos os anos, vítimas de estupros ou má-formação congênita em sua gravidez, optam por retirar a criança e se sentem incompreendidas pela igreja católica em seu caso pessoal.

Assim, como na Igreja Católica Apostólica Romana, as divergências de opinião estão em todo o lugar: não só entre as centenas de denominações evangélicas espalhadas pelo Brasil - número esse devido às divergências de opinião quanto ao próprio conteúdo da Bíblia - como dentro das próprias igrejas. Segundo Dennis Alan, pesquisador bíblico protestante, alguns sugerem o começo da vida na viabilidade do feto e sua capacidade de sobreviver fora do útero. Tal definição, porém, é considerada como bastante controvertida e está constantemente se alterando. Mesmo depois do nascimento, um recém-nascido é totalmente dependente da proteção e do cuidado de outros. Outros, portanto, sugerem que a vida começa com a primeira respiração. É verdade que a vida de Adão começou deste modo (Gênesis 2:7) e que os corpos ressuscitados foram considerados vivos quando o espírito respirou sobre eles e eles se levantaram (Ezequiel 37:810; Apocalipse 11:11). Mas esses dados não fazem consenso de que uma criança ainda não nascida - Adão nunca foi um feto - não esteja viva. As controvérsias continuam com argumentos, muitas vezes, que indicam que não podemos usar o caso excepcional da criação de Adão para justificar a matança de seus inocentes descendentes. Diane Dew, em seu artigo intitulado Choice has a Name, do The Milwaukee Journal - de 21/2/1992 -, diz que Deus reconheceu a importância das crianças desde antes de nascer. A Bíblia teria apontado que, freqüentemente, um ser divino falaria sobre pessoas que foram escolhidas, mesmo antes do nascimento, para papéis especiais nos serviços sagrados (Salmo 139:13-16; Isaías 49:1, 5; Jeremias 1:5; Gálatas 1:15). Dessa forma, contesta que, mesmo antes do primeiro respirar, Deus leva em consideração a vida humana, e não só após seu nascimento.

\section{A Comunidade Evangélica Projeto}

Vida, através de um de seus pastores, manifestou opinião quanto à utilização de células-tronco da seguinte forma:
A vida que Deus nos deu deve ser preservada sempre. O tratamento médico é de fundamental importância, mas através da fé (certeza das coisas que se esperam e não se vêem) cremos que é possível chegar a uma linha de estudos que não necessite sacrificar nenhuma forma de vida, quer humana ou mesmo animal (Fantástico/Rede Globo - 25/11/2007).

A opinião da comunidade evangélica encontra respaldo em uma recente descoberta em que cientistas conseguem criar célulastronco com as mesmas características de células embrionárias, a partir de uma célula de pele humana adulta. Não se faz necessária a destruição de embriões humanos. Dessa forma, essa nova tecnologia parece ter o potencial para realizar um acordo entre religião e pesquisa científica.

Apesar de a instituição Igreja ser entendida, muitas vezes, como um centro de uniformidade de opiniões, nem todos os assuntos são absorvidos em comum pelo público de fiéis. A concepção da própria vida parece controvertida no meio cristão. Alguns chegam a alegar que se a origem da vida se deu no sopro de Deus em Adão, parece ser questionável que a concepção de vida possa acontecer somente de uma relação sexual entre homem e mulher. Controvérsias... Parece que o conceito de humanidade em diversos ambientes - na ciência, na religião, no dia-a dia, encontra-se em franca turbulência. Diversas são as traduções acerca de tal vida humana. Em uma atualidade permeada pela controvérsia - turbulência - na delimitação da fronteira que separa o humano do nãohumano, encontramos no pensamento de Bruno Latour uma possibilidade bastante fértil de aprofundamento do tema. Vejamos por que.

\section{As Redes e a Controvérsia}

\subsection{As Redes e os Híbridos}

Vivemos em uma realidade permeada por instabilidades que escapam de nosso controle. Hoje nos encontramos envolvidos em situações que não conseguimos dar conta a partir daquilo que entendemos por uma atitude moderna. A atitude moderna, no âmbito do conhecimento, parece se caracterizar por uma busca de solidez na construção do conhecimento, da ordem, da exatidão, da estruturação e da classificação. 
Assentada sobre a idéia de portos seguros de lugares sólidos e de classificações rígidas que ordenam as regularidades - mantém longe toda e qualquer desordem. Estamos diante de um olhar binário, uma construção de certos e errados, de "dentros" e "foras" (Bauman, 1999).

Temos, na história da humanidade, vários exemplos de tentativas de busca dessa "ordem" e dessa estabilidade. Bruno Latour (1994), ao emblematizar tal perspectiva moderna, nos remete aos trabalhos do cientista Robert Boyle e do filósofo Thomas Hobbes. Boyle criou um método, através de uma abordagem empírica, que estudava a natureza - em um ambiente isolado de qualquer política, como é o caso dos laboratórios de hoje em dia. Por sua vez, Hobbes apresentou um ponto de vista onde os humanos eram os soberanos, negando a possibilidade de ser levada em consideração qualquer entidade sobrenatural, transcendental, de modo que a figura do ator que foi designado pela sociedade em geral com o título de soberano, detinha a força, o poder, a dita representação da coletividade humana.

Tal quadro apresenta como consequiência, dois pólos opostos e antagônicos que, segundo Latour, fundaram a Constituição da Modernidade. São produzidas abordagens - modernas - que sempre se localizam ora assentadas na sólida sociedade, no humano, ora no conhecimento, na potente natureza. Vemos dois universos dispostos em oposição - um jogo binário moderno (Bauman, 1999). Com isso, a Modernidade constitui um rompimento entre a natureza e a cultura, surgindo - desse rompimento um tempo em que não há ligação entre um passado e um futuro. Há sim uma busca pelo que está em frente, que supera o que está para trás. Cria-se uma percepção temporal na direção do progresso, da superação e da extinção do que seja "falso". Tenta-se alcançar o perfeito, a ordem plena. Ao serem alcançados tais ordenamentos, apagam-se tais processos de produção ocasionando a perspectiva de "naturezas em si". Constrói-se um mundo de entes transcendentais desamarrados da imanência do mundo. Por sua vez, o mundo imanente, da política, das humanidades, parece - emblematizado por Hobbes - totalmente dicotômico em relação a tais naturezas. Duas purezas - humana e não-humana - disposta em oposição.
A Modernidade - caracterizada como um baluarte das certezas fundamentais - estabelece fronteiras que se querem puras fazendo com que o conhecimento se estabeleça como um sólido "em si" e construindo, simultaneamente, uma oposta "solidez humana/social/cultural". Na atualidade, parece chegar o momento em que tal movimento ordenador, tal Constituição Moderna começa a sofrer abalos. Vemos uma atualidade de intensa hibridação, uma tessitura de fatos que misturam intensamente aspectos políticos, industriais, financeiros, científicos, religiosos, etc. As fronteiras entre humanidade e não-humanidade parecem permeadas pela névoa.

No intuito de delinear um novo entendimento que reencontre os laços entre natureza e sociedade, Bruno Latour articula um novo modo de se conceber o conhecimento. No presente trabalho, estamos em sintonia com seu modelo de redes sociotécnicas. Este consiste em uma negação da cartilha moderna. Tal modelo trás potência para o híbrido - para a mistura - e desloca o olhar moderno. Concebe que todo saber - inclusive a ciência - se expande utilizando uma rede de purificações. Por purificação, Latour designa práticas que detém a intenção de se separar o humano/social do não-humano/natural - constituindo, nesse momento, o puro e o impuro simultaneamente - sendo o impuro aquele que mistura natureza e cultura. Porém, tal expansão só ocorreu devido às intensas mediações, associações do puro com o impuro. Tais misturas, Latour denomina híbridos ou práticas de hibridação/ tradução.

Neste sentido, para que a ciência moderna se consolide, são necessárias a utilização de manifestações que circulam "de mão em mão" e, no decorrer desse percurso, tais manifestações vão se modificando. Um fato, para se manter como tal, é sempre um coletivo. Necessitará, sempre, das amarras que são estabelecidas para configurá-lo. A rede, para se expandir, precisa justamente da mistura/ transformação/apropriações de humanos e de não-humanos. Rede é circulação.

\subsection{As Redes e a Circulação}

Para caracterizar este processo circulatório de mistura e transformação de 
humanos e de não-humanos, Latour utiliza um bom exemplo, em seu livro intitulado "Esperança de Pandora" (Latour, 2001). O sociólogo das ciências acompanha uma pesquisa realizada na floresta amazônica, onde as ciências botânicas demarcam, separam e catalogam partes da floresta. Latour, ao se deparar com a floresta, se dá conta que esta é um laboratório. Já está “escaneada”, permeada por inscrições de todos os tipos. O trabalho parte de tais inscrições. Amostras são colhidas para que possam embasar novos argumentos. Estas são armazenadas em um arquivo. Vemos uma floresta que passa a "residir" no arquivo. Essa floresta, simultaneamente, é e não é o arquivo. $\mathrm{O}$ arquivo, ao mesmo tempo em que é a floresta, tem intrínseco outros fatores envolvidos que fogem do que se quer natural, realizando assim um hibridismo entre "coisa" e "signo". Novas qualidades, possibilidades, virtualizações surgem com o arquivo-floresta. O que entendemos por realidade/natureza parece sempre depender desses intensos trabalhos de deslocamento em uma rede de trabalhos intensa - rede essa que mistura humanos e não humanos em um mesmo fôlego.

A conseqüência decorrente dessas séries de hibridações é a progressiva e constante circulação dos artefatos nessas redes sociotécnicas. Esse modelo diferenciase bastante da percepção moderna de um humano dicotomizado do não-humano. Estamos diante de uma circulação constante, um tecido sendo alinhavado pelas traduções, por um constante deslocamento a re-construir humanidade e não-humanidade, sociedade e natureza. Essa circulação muda o foco de visão, do conhecimento e da ciência, para todo esse processo de transformações que mantém a circulação ativa, realizando, de modo vertiginoso, etapas de negociações materializadas por um instrumento/mediador.

Um fato se consolida quando se mantém circulante, se transformando e se transformando, com isso formando categorias - sendo entendidas como caixas-pretas (Latour, 2000). A caixa-preta consiste em um argumento que adquiriu vários aspectos humanos e não-humanos, e que contém diversas articulações ou hibridações. Estas fazem com que o argumento se torne algo inquestionável, adquirindo característica de solidez. Sempre que humanos e não- humanos se apropriam dos argumentos, estes se solidificam um pouco mais, deixando um rastro de argumentos implícitos que legitimam o enunciado. É por esta razão que a firmeza de um artefato está diretamente ligada àqueles que o mantém em movimento. A referência, o fundamento, está em constante circulação nas mãos de humanos e não-humanos.

Para que a caixa-preta seja aberta, é necessário enxergar sua condição de construção feita a partir de mediações e de traduções diversas. Quando este sistema de traduções para de circular por causa de algum obstáculo, esse enunciado será jogado para a "falsidade". Nesse momento, estaremos imersos em uma controvérsia, em que cada representante dos humanos e dos não-humanos tentarão defender com unhas e dentes os seus argumentos e contra-argumentos. Tal controvérsia vai se intensificando e abrindo a caixa-preta que, até então, carecia de uma historicidade às claras. Diversos são os actantes envolvidos em tais embates. Vemos coletivos a envolver dinheiro, governos, religiões, ciência, objetos, etc. Vemos um fervilhar de intensas traduções que, acabam por deixar a caixa-preta translúcida.

Tais embates podem dar acesso ao surgimento daquilo que Latour chama de objeto novo. Seu surgimento inaugura sempre um novo tempo, pois realinha forças e reconfigura os opostos. Tal objeto, depois de formatado, pode seguir em um novo circuito de apropriações. Se isto ocorrer, estaremos diante de uma nova caixa-preta. O sólido fato, a natureza, é sempre uma caixa-preta que depende de um coletivo de humanos e nãohumanos que o coloca em circulação.

A concepção das redes parece não mais possibilitar a legitimação de uma instância superior que controle os fluxos. Os coletivos são transbordantes e produzem constantemente realidade a partir de redes que descentram aquilo que existe. As misturas deslocam os espaços e novas geografias são construídas por meio deste movimento de hibridação. Sempre tecemos - humanos e nãohumanos - nossa realidade e a nós próprios. A controvérsia parece ser de suma importância, pois nesta desponta o potencial de intensa desconstrução de realidades e construção de novas existências. É com tal perspectiva que voltamos nosso olhar para uma atualidade permeada pelas novas biotecnologias da reprodução. "Humanidades artificiais" 
são quimeras que, atualmente, afrontam a estabilidade das fronteiras do humano - e estas, para se manterem estáveis, necessitam se purificar de tais aberrações. Dessa forma, humano e natureza se aliam contra o horror do artifício. Intensas controvérsias despontam nesse terreno. Consideramos o modelo de redes e controvérsias como de singular importância na abordagem de tal atualidade

\subsection{As Redes e as Controvérsias no Ambiente Tecnológico}

Sendo o modelo deredes sociotécnicas pensado a partir dos fluxos, das mediações, e tendo na controvérsia um momento de singular importância, de abertura de caixas-pretas, pensamos que a análise das controvérsias pode nos ser bastante fértil em sua abordagem.

\begin{abstract}
A análise das controvérsias técnicas e cientificas ganhou destaque no período de 1970, quando ocorreu um crescimento das pesquisas sociológicas que procuravam entender os fundamentos do comportamento da comunidade cientifica e da formação e evolução das idéias dessa comunidade. Foi a partir de pesquisas feitas por Nelkin e Mazur (in Velho \& Velho, 2002) que se começou a desenvolver com maior intensidade e profundidade os estudos de controvérsias. Esses autores buscaram focalizar e compreender a maneira pelo qual o poder do conhecimento científico dependia de negociações e debates entre as partes interessadas, envolvendo diferentes segmentos da sociedade - o que já nos dá uma pista de que acompanhar as controvérsias é, igualmente, apreender a mistura entre conhecimento e sociedade. Controvérsias referem-se a disputas, uma discussão em que se alegam razões pró ou contra, com objetivo de uma conclusão, acordos, entre pessoas sobre um assunto de interesse comum (Nobre \& Pedro, 2006: 13).
\end{abstract}

Vemos aqui uma perspectiva da ciência entrelaçada com o social. A tecnociência é a própria sociedade à qual se misturou, formando-se uma hibridação. Seus entrelaçamentos se constituíram e foram desenvolvidos conjuntamente. Desses relacionamentos complexos de humanos e não-humanos, técnica e social, surge a vida da ciência. Não existem abismos entre técnica e humanidade.

Em todo processo tecnológico, segundo Schumpeter (in Guesser, 2005), existem três fases: A invenção, a inovação e difusão. A invenção é um momento inicial onde é configurada uma novidade. Se existirem controvérsias nessa etapa, estas se limitam ao ambiente tecnocientífico. Por sua vez, a fase da inovação
(...) é bem mais complexa, não no nível conceitual, mas no sentido das inúmeras conexões que este momento do processo tecnológico envolve. Diz, sobretudo, respeito à sua relação com a primeira vez que um instrumento, sistema ou produto é produzido e comercializado. (...) É, também, uma etapa onde o processo deixa o espaço restrito dos laboratórios e ganha espaço e abrangência social. Esta é uma fase do processo onde um dado produto tecnológico pode causar maior reação de aceitação ou de recusa - causando controvérsias - dentro de uma dada sociedade, pois é o momento em que este passa a ser produzido e disponibilizado em grande escala aos usuários (Guesser, 2005: 78).

Para que a inovação se desenvolva a partir da invenção, necessita-se de uma aceitação/aprovação que desponta de grandes polêmicas que existirão no decorrer do processo - ponto onde existirão controvérsias. Tal fase é bastante complexa, pois se desenvolve conforme as múltiplas exigências articuladas à novidade citada anteriormente, causando turbulências de controvérsias significativas para a sucessiva evolução.

Já a difusão não gera maiores controvérsias. Na fase anterior já houve todo um processo de negociação de parâmetros estabelecidos por todos - e ficando a difusão como fase final e aceita - até a ocorrência de outras modificações.

É a partir da inserção de uma novidade na realidade que esta pode se tornar um atrativo social e tecnológico - no sentido de aprovação ou rejeição coletiva. Notamse, segundo Guesser, como as disputas e os conflitos possuem forças e poderes suficientes para fazer existir o novo.

A maneira mais fácil de identificar o grau de relações que um dado conhecimento tecnocientífico possui com relação à sociedade em que se produz é a partir das suas expressões controversas. Acompanhando estes processos de disputas e de conflitos é possível perceber a força que cada um desses atores desempenha no conjunto, sejam eles humanos ou nãohumanos, e remontar a complexa trama de relações, num processo contextual e histórico (Guesser, 2005: 80).

Nelkin (in Guesser, 2005) descreve que a ciência sempre teve um relacionamento de enfrentamento com a coletividade. Tem havido, por parte da coletividade humana, um misto de valorização da ciência e de medo de suas intervenções. $\mathrm{O}$ cientista faz o bem ou o mal? Essas têm sido perguntas que têm gerado grandes controvérsias políticas e morais. Os conflitos tecnocientíficos acabam por transbordar seu ambiente mais restrito e são levados para fora da área restrita da 
tecnociência.

Com toda essa controvérsia gerada em torno das tecnologias, as decisões acabam sendo tomadas por meio de negociações entre os diversos envolvidos. Essas turbulências são motivadas por tentativas de controle das tecnologias, poderes diversos. As controvérsias tecnocientíficas, portanto, são sempre políticas e envolvem interesses plurais também. Guesser (2005), apoiado no pensamento de Nelkin, aponta que as controvérsias são impulsionadas por diferentes motivações - contabilizando, ao todo cinco tipos ${ }^{3}$.

Um primeiro tipo de controvérsia diz respeito aos que disputam por causas morais e religiosas - de onde tiram suas motivações. São conflitos em que figuram os ditames morais dos pesquisadores - questões impostas sobre o certo e o errado, o bem e o mal. Sendo assim, os principais atores nessas controvérsias são, de um lado, os cientistas - defendendo suas pesquisas - e de outro, os religiosos - moralistas ameaçados em seus direitos de crenças e valores.

O segundo tipo apresenta preocupações no âmbito ambiental, político e econômico. Envolvem indivíduos sempre atentos quanto a ameaças as integridades sociais. A motivação destes conflitos é a degradação ou o uso indevido de bens comunitários, ambiente de trabalho, etc e também as questões políticas e econômicas que se impõe a toda a coletividade.

O terceiro tipo de controvérsias se caracteriza pelos perigos e riscos que a pesquisa da tecnociência pode ocasionar para a população em relação a novos padrões de consumos, novos alimentos com aditivos químicos, conservantes, corantes, etc. Inseguranças ocasionadas pela própria tecnociência em disputas abertas sobre qual a melhor dieta, vida mais saudável, efeitos colaterais e etc.

A quarta questão diz respeito à inserção da tecnologia junto às expectativas humanas e metas comunitárias. Questionase a papel regulatório do governo em prol dos cidadãos, em defesas de direitos individuais e coletivos. Os procedimentos da tecnociência - quando adotados e impostos ao corpo social, regulamentado pelo governo comumente traz conflitos, pois pode conduzir a afrontamento aos direitos individuais de privacidade e liberdade de escolhas. As leis são regulamentadas em cima de pareceres técnicos e impostas aos cidadãos - e eles, com valores democráticos, questionam o tipo de procedimento, exigindo sua participação.

Um último tipo de conflito é o de grupos tecnocientíficos, ocorridos no interior dos laboratórios.

\footnotetext{
São exemplos deste tipo de controvérsias as disputas por financiamentos, por patentes e por competitividade no mercado. A questão de divergência entre concepções diferentes do papel da ciência para as sociedades também move intensos e acalorados debates, por vezes extrapolando o domínio específico das academias e laboratórios (Guesser, 2005: 87).
}

Ao voltarmos nossos olhares para o atual ambiente de instabilidade nos sólidos referenciais acerca da vida humana, apostamos na perspectiva de uma abertura de caixa-preta, em uma controvérsia a misturar intensamente humanos e não-humanos. Tal controvérsia é de singular importância, pois abrange todos os tipos de conflitos abordados por Guesser. Apostamos em uma flexibilidade da condição humana - que parece ainda não ter perspectiva de fechamento no horizonte. Estamos imersos em um turbilhão, em uma efervescência, onde diversos são os actantes ${ }^{4}$ a negociarem a existência humana - gerando controvérsias que parecem problematizar uma realidade e redesenhá-la.

\section{A Vida Humana: a cartografia de uma controvérsia}

Com o intuito de ilustrar a dinâmica das controvérsias que permeiam a atualidade e intabilizam a concepção de vida humana, analisamos artigos das revistas Época - em sua versão on-line - Consulex - específica da área do Direito - e de jornais - como o Jornal do Brasil e a Folha de São Paulo - também em suas versões eletrônicas, pois tais periódicos são de grande visibilidade social. Estes acabam por ajudar bastante nas repercussões dos argumentos diversos e na propagação das

\footnotetext{
${ }^{3}$ Cabe ressaltar que são, mais do que uma realidade, um recurso metodológico. As controvérsias presentes em nossa sociedade são muito mais complexas, devido a combinações e misturas de diferentes tipos de disputas. Apesar disso, tal recurso nos ajuda a verificar as motivações principais que sustentam uma controvérsia na tecnociência.

${ }^{4}$ Termo utilizado por Bruno Latour para designar humanos e não-humanos, visto que o conceito "ator", comumente utilizado nos estudos da Sociologia, é utilizado para representar apenas os humanos.
} 
controvérsias.

Como critério de pesquisa e devido ao intenso dinamismo da área, delimitamos um curto período dos periódicos - que se situa entre 2007 e 2008 . Nosso foco se situou nas matérias que visavam às polêmicas acerca das novas biotecnologias da reprodução - como as células-tronco - já que estas são o alvo central de nossa pesquisa graças ao seu caráter controverso, multinacional e atual. As matérias analisadas apontam para questões sobre o início da vida do humano e dos direitos do mesmo, sendo estas multidimensionais, isto é, transitam por campos como o religioso, o jurídico, o político, o filosófico, o econômico e o científico - não se encerrando nesses campos.

Analisando o artigo da Revista Jurídica Consulex de março/2008, Francisco Rodrigues, desembargador aposentado do Tribunal de Justiça de São Paulo, parece apontar que a discussão central no julgamento de inconstitucionalidade da Lei de Biossegurança brasileira é o conceito de vida, quando afirma que

Qualquer nova lei ordinária esbarraria em arrastadas polêmicas porque o que está por detrás das críticas redacionais é uma questão muito mais profunda, filosófica e religiosa: O QUE É VIDA? (Rodrigues, 2008: 28).

No sentido de tentar responder a tal colocação, o autor parece apontar para uma espécie de escala de valoração da vida. Desenvolve que a valorização desta vida existe mesmo quando se mata um para salvar muitos.

Quando a China, por exemplo, com sua imensa população, executa em público, criminosos (...) o faz supondo que assim agindo está, de forma indireta, mas eficaz, valorizando a vida, no seu sentido mais abrangente (Rodrigues, 2008: 29).

Parece que temos, aqui, uma tradução da vida dentro de uma escala de valores quantitativos. Mata-se um para salvar muitos. Mais ainda, vemos uma vida valorada por critérios que estabelecem uma previsão do futuro. Se conseguirmos prever a morte de muitos, corta-se o mal pela raiz. Estamos no campo das probabilidades. No caso das pesquisas com células-tronco embrionárias, o saber a valorar - e valorizar - a vida humana parece ser o científico.

Quando (...) os cientistas favoráveis às experiências com células-tronco embrionárias insistem nesse novo campo de pesquisa, assim o fazem não porque sejam, em sua vasta maioria, excêntricos Mengeles nazistas (...). Pensam nos benefícios que tal pesquisa pode trazer para a humanidade (Rodrigues, 2008: 29).

A tradução de vida como valor fica ainda mais evidente quando aponta que os cientistas reconhecem

(...) que num embrião de cinco ou dez células há, de fato, uma vida, embora incipientíssima (...). Pessoas atacadas de diabetes (...), Alzheimer, Parkinson e inúmeras outras doenças incuráveis (...) estão vivas também. Sofrem e merecem maior proteção e alívio mais que aquelas cinco ou dez células do embrião que será sacrificado (...). É uma questão de pesar o mal menor (Rodrigues, 2008: 29).

Mas qual é a balança que pesa o mal maior e o mal menor? Parece que o autor reconhece tal balança nas lógicas de mercado e na tecnociência quando afirma que

Outros países não darão a mínima importância para nossa declaração de inconstitucionalidade, pelo Supremo. Até aplaudirão a inércia de um possível concorrente nas pesquisas e grandes descobertas. Continuarão com suas experiências e depois nos alugarão, por altíssimo preço, a tecnologia que, por teologia, recusamos aos nossos cientistas (Rodrigues, 2008: 29).

Vemos aqui, claramente, a produção de um divisor de águas entre o bem e o mal, pólos opostos em um campo de batalha. Por um lado a tecnociência - que decide sobre o progresso - e de outro a teologia. Tal divisão também pode ser percebida no argumento de Marco Segre, professor emérito da Faculdade de Medicina da USP, quando afirma, também na Revista Jurídica Consulex de março/2008, que

Todo avanço produz, entretanto, medo, em certas categorias da sociedade, momente se aparentemente afronta alguns dos tabus criados por grupos conservadores, precisamente as religiões (Segre, 2008: 31).

Tal alegação acerca do medo do novo é igualmente abordada em matéria da Folha de São Paulo on-line - de 10/03 2008. Nessa matéria, o Geneticista Oliver Smithies, um dos vencedores do Prêmio Nobel de Medicina ou Fisiologia de 2007, parece dar uma resposta a esse tema em sintonia com o artigo anterior, quando alega que:

Não acho, na verdade, que seremos um campo controverso, se esperarmos um pouco, diz. Muitas coisas, quando começam, são controversas. Depois, nos acostumamos, e elas deixam de ser (Garcia, 2008). 
O tempo progressista da ciência parece, aqui, estar sendo produzido como dotado da capacidade de amenizar as questões controversas, de iluminar o olhar religioso e da sociedade de modo geral. Religião obscurantista de um lado e ciência do outro. Segre defende que a concepção de vida é algo estritamente do âmbito científico:

Tome-se como exemplo o tabu da demarcação do início da vida humana. A vida não se inicia na fecundação do óvulo. Esse episódio é apenas uma das etapas (...) da construção de um novo ser. É importante não confundirmos ciência com crença. Cientificamente, pode-se dizer que, na fecundação, o espermatozóide penetra no óvulo, há uma soma de genes, e inicia-se a produção das outras células, que, em conjunto, constituirão o novo ser (Segre, 2008: 31).

A idéia aqui parece ser a purificação da ciência de tudo aquilo que remeta à religião - entendida como impureza, pois

(...) se quisermos, consideraríamos pecaminosos todos os progressos científicos, inclusive o de elevarmos a expectativa média da vida humana em algumas décadas. Será que é isso realmente que Deus quer? (Segre, 2008: 31).

Deus ou ciência? Qual o porta-voz da vida? Mais ainda... Será que Deus não estaria querendo o bem que a Ciência pode trazer? Um Deus como aliado da Ciência parece ser produzido aqui. Ambiente de intensa turbulência este que traduz - media a existência. Segre parece acreditar em uma concepção bastante cultural da vida quando aponta que

(...) o desenvolvimento da vida é um continuum, e que são fatores culturais que, para fins de convívio harmônico da sociedade demarcam seu início. E, no caso da clonagem, quando não há fecundação, dirse-á que não houve vida? A ovelha Dolly não viveu? (Segre, 2008: 31).

Boa questão. Porém, se a vida é demarcada pela cultura e pelo social, a ovelha Dolly - um não-humano - teria vivido ou não? A questão parece continuar se impondo. Imersos na mesma temática, Jaime Lopes assessor parlamentar da câmara dos deputados e coordenador nacional do movimento em Defesa da Vida - Brasil sem Aborto - e Hermes Nery - membro do Grupo de Trabalho em Defesa da vida da CNBB - em artigo da Revista Jurídica Consulex - de março/2008 analisam o pronunciamento do ministro Ayres Britto na audiência pública de cinco e março de 2008, do STF. Traduzem tais redes como crime de lógica, uma utilização da filosofia, do pensamento, para tornar legítimo o assassinato de vidas humanas.

\begin{abstract}
O que podemos esperar quando a Suprema Corte de um país reconhece que a constituição só deve proteger a pessoa nascida, residente, nata e naturalizada, e que não há pessoa humana sem o aparato neural que lhe dá acesso às complexas funções do sentimento e do pensar - e que, portanto, fora disso, é legítimo eliminá-la (...). Estamos (...) diante daquilo que Albert Camus chamou de criminosos de lógica, em que o crime se torna matéria de raciocínio (Lopes \& Nery, 2008: 35).
\end{abstract}

Os autores procuram se aliar com estatísticas sobre opinião pública em relação ao aborto - associando tal prática com a pesquisa com células-tronco embrionárias - para enfatizar, ainda mais, uma espécie de "isolamento moral" do ministro, considerado como se atendo a uma lógica assassina e particular.

(...) o dado mais significativo dessa pesquisa foi que $87 \%$ da população ouvida condenam a interrupção da gravidez por considerar essa prática moralmente incorreta. Diríamos nós, interpretando-o, que a maioria absoluta do povo brasileiro rejeita o aborto em qualquer fase da gestação do nascituro (Lopes \& Nery, 2008: 35).

Voltando ao artigo de Francisco Rodrigues, podemos ver a importante mediação dos não-humanos, da técnica, na construção da realidade quando, inflamado, defende que

Não se argumente que as células-tronco adultas
podem exercer exatamente a mesma função que
as embrionárias. Isso não está ainda comprovado.
(...) Trancar, hoje, a possibilidade de fazer essas
experiências apenas por considerações religiosas,
ou semânticas jurídicas, é um atentado ao progresso
cientifico do país (Rodrigues, 2008: 29).

Com um possível desenvolvimento das pesquisas em biotecnologias da reprodução, poderíamos encontrar um quadro onde células adultas podem assumir o papel das células embrionárias. Tais células poderiam amenizar um conflito entre interesses diversos religiosos e científicos, por exemplo - diluindo a atual controvérsia. Enquanto não temos tal tecnologia disponível, encontramos intensa instabilidade, diferentes actantes a traduzirem, de modo diverso, a vida humana.

Uma das questões bastante importantes e cruciais no debate parece ser a da morte - ou assassinato - dos embriões. Em uma entrevista dada ao Jornal do Brasil do dia

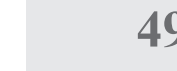

,


comissão de bioética da Conferência Nacional dos Bispos do Brasil - CNBB -, professor de teologia moral e bioética, ao saber do anúncio de uma nova técnica para retirada de células-tronco, sem a utilização de embriões, comemorou a notícia e ressaltou que

Uma coisa é pesquisar com embriões de animais; outra seria pesquisar com embriões humanos: eles são portadores dos direitos próprios de todo ser humano, não importando a fase evolutiva na qual se encontrem. Aliás, é isto que a Constituição brasileira prevê (Moser, 2007, grifo nosso)

O que o frei aponta seria um problema de inconstitucionalidade das pesquisas com embriões humanos no Brasil. Existiria uma inconsistência criada pelos cientistas e pelo próprio Estado já que este último deveria garantir a proteção integral ao nascituro. Toma como aliados a militância da igreja contra o uso de embriões em pesquisas e as leis de um Estado brasileiro dito laico. Ao utilizar como base de apoio a constituição do Estado brasileiro, o clérigo estaria tentando legitimar seus argumentos através do órgão máximo de normatização da vida humana no país - sendo que este minimiza a presença da religião nas decisões políticas, para haver clareza e universalidade nas leis, políticas sociais, etc. Dessa forma a igreja estaria apontando sua posição através de um órgão de grande força, mas que, em seu fundamento, afasta argumentos religiosos de sua constituição. Vemos, aqui, que religião e ciência não constituem pólos totalmente homogêneos.

Abordando o mesmo tema em entrevista concedida ao Jornal do Brasil online, o presidente da Comissão de Bioética do Hospital das Clínicas de São Paulo, Cláudio Cohen, em 04/03/2008, defende que a definição de morte não está solidificada na ciência, ou seja, não há um ponto certo e definitivo sobre quando há morte ou quando há vida. Como um exemplo, Cohen traz que a morte, anteriormente determinada pela parada cardiorrespiratória do paciente, foi superada pelo conceito de morte cerebral - e mais recentemente pelo de morte encefálica. Com isso chega à conclusão de que

A gente não pode parar o progresso da humanidade simplesmente porque há um valor que pode estar sendo questionado pela Igreja... Não é que você está matando alguém, se essas células-tronco seriam jogadas fora e se, ao invés disso, forem feitas pesquisas, isso me parece bastante coerente (JB
O autor tenta criar uma veia racional pela qual o leitor deve se levar a questionar os entraves impostos pela igreja, apontando a falta de coerência da militância religiosa e como isso retarda um progresso. Dessa forma, separa-se a igreja da evolução. Criase a idéia de que a religião não passa de uma barreira para o bem estar humano mostrando claramente a dicotomia entre igreja e ciência. $\mathrm{O}$ agente retrógrado e o evolutivo - o agente do progresso.

Em matéria publicada em 10/03/2008 pela Folha de São Paulo on-line - já citada anteriormente no presente artigo - sobre a questão da inconstitucionalidade das pesquisas com células-tronco embrionárias, em julgamento no Supremo Tribunal Federal do Brasil, o geneticista Oliver Smithies coloca sua posição sobre tal questão de uma forma bastante pessoal. Aponta que "Gostaria que o Supremo Tribunal pensasse em células-tronco de modo diferente". Logo depois explicita essa nova forma de vislumbrar a pesquisa:

Imagine que eu seja um jovem morto num acidente de carro. Há partes do meu corpo que ainda são úteis e podem ser dadas a outras pessoas para manter suas vidas. Então, parte de mim viveria em outra pessoa. Se uma célula-tronco embrionária é feita [para terapia], aquele embrião não é morto, aquele embrião dá vida a outra pessoa, por fim. (Garcia, 2008, grifo nosso).

Podemos perceber que o geneticista estaria apontando as células-tronco embrionárias com o mesmo viés conceitual dos transplantes de órgãos. Dessa forma, ele estaria tentando conectar os sentimentos envolvidos nos transplantes de órgãos para os tratamentos com células-tronco embrionárias. Tal conexão se dá através da comparação de que ambos os processos seriam a mesma coisa, criando apenas uma nova conceituação para os transplantes, isto é, os macro transplantes - de órgãos - e micro transplantes - de células. Com isso o geneticista estaria conferindo as célulastronco embrionárias o mesmo valor conceitual de um órgão humano, com chances de ser transplantado, e ao embrião a capacidade de ser um doador em potencial.

Cilene Pereira e Mônica Tarantino, em publicação da Revista Isto É de 12 de Março de 2008, manifestam um descontentamento no que se refere ao adiamento da decisão do Supremo Tribunal Federal a liberação das 
pesquisas com células-tronco embrionárias:

$\mathrm{O}$ adiamento da decisão sobre a liberação das pesquisas com células-tronco embrionárias no Brasil retardará ainda mais o desenvolvimento no País de uma área da ciência que, no mundo, encontra-se em franca efervescência (Pereira \& Tarantino, 2008)

As autoras parecem defender a utilização das pesquisas com células-tronco como a única forma de conseguir, para o Brasil, certa autonomia nesta área em relação a outros países do mundo.

Enquanto o mundo experimenta pregresso, o Brasil caminha a passos lentos. Até a decisão do STF, as pesquisas continuam liberadas. Mas são poucos os que investem nas embrionárias, por causa da falta de recursos e da identificação quanto ao futuro dos estudos aqui (Pereira \& Tarantino, 2008)

Elas exaltam a questão do atraso brasileiro frente ao mundo. Tal argumentação configura um clima de competição no campo das pesquisas com células tronco embrionárias. Dessa forma, é perceptível a dicotomia do avanço tecnológico e do atraso, sendo que há uma personificação dos agentes do progresso e da estagnação tecnológica na figura do STF e na dos "poucos e obstinados cientistas que trabalham na área".

Em 05/03/2008, em matéria do Jornal do Brasil, o advogado Luiz Roberto Barroso aponta que

Jogar um embrião fora ao invés de permitir que ele salve vidas é uma decisão de difícil sustentação ética (...). Estaríamos sacrificando a ciência, trocando a esperança de salvação das pessoas por coisa nenhuma, porque nada que se decida aqui afetará a sorte dos embriões. (JB Online, 2008, grifo nosso)

A defesa do autor é sustentada em uma visão fatalista do processo que tramita no STF, em que ambas as decisões, aprovação ou reprovação da utilização do mesmo em pesquisas, causariam um efeito igual, ou seja, a morte dos embriões. Percebemos aqui, como já abordamos anteriormente, a valoração do destino dado aos nascituros. Ciência e vida humana se misturam a ponto de que sacrificar as pesquisas é sacrificar humanos que seriam beneficiados por ela, conferindo a ciência um caráter de salvação.

Por intermédio dessa breve análise da controvérsia que fizemos a partir de material midiático, podemos perceber a grande flexibilidade do conceito de vida humana na atualidade. Tal flexibilidade parece apontar para intensas e múltiplas traduções desta mesma vida humana que são feitas por actantes diversos. Humanidade - a partir de nosso entendimento - parece ser um formato negociado no mesmo fôlego em que tais traduções ganham a cena e a instabilizam simultaneamente a ocorrência de tentativas de sua redefinição.

\section{Considerações Finais}

Aquilo que entendemos, até então, por vida humana parece ser desconstruído, na atualidade, a passos largos. Se tínhamos vida humana como uma representação bastante fixa, na atualidade, com a participação singular das novas biotecnologias da reprodução, vemos um tecido bastante complexo sendo produzido. Actantes diversos se entrecruzam em traduções múltiplas e acabam por delinear novas geografias, novos ordenamentos. Entendemos como bastante fértil, em um terreno de tamanha instabilidade, a concepção das redes na abordagem do conceito de vida humana. Não estamos aqui, nativos de uma concepção de representação. Não... Pensamos a partir da circulação, das traduções diversas que colocam o humano em circulação. De tradução em tradução, objetividade e subjetividade são trazidos à existência.

Tentamos, nesse artigo, desenvolver uma abordagem amoderna do humano. Em tal perspectiva, focalizamos as híbridas conexões que produzem-e reproduzem simultaneamente - tecnologia e humanidade. Nenhum abismo entre os dois. Como já afirmara Kunzru,

(...) estamos dentro daquilo que fazemos e aquilo que fazemos está dentro de nós. Vivemos em um mundo de conexões - e é importante saber quem é que é feito e desfeito (Kunzru, 2000: 36).

Temos, portanto, uma amarração de humano e não-humano. Assim como um ciborgue, a humanidade pode ser entendida como individual e, ao mesmo tempo, coletiva. A parte está imbricada com o todo, é atuante na rede, e dele também é uma expressão. É ao mesmo tempo produto e produtor.

A vida humana entendida como rede, é um emaranhado de actantes híbridos, em que tal diversidade conectiva não pode ser contida em um centro único dado a priori. Temos um coletivo. Juristas, tecnologias, 
leis, instituições, governos, mídia, cidadãos comuns, ciência se entrelaçam e conduzem o conceito de humanidade adiante. Entendemos, portanto, que os ordenamentos - entre eles aquilo que entendemos por humano - são desenhados por intermédio dos intensos e turbulentos movimentos de tradução.

\section{Referências Bibliográficas}

BRAZ, M. Bioética e Reprodução Humana. In Schramm, F. R. \& Braz, M. (Org.). Bioética e Saúde: Novos tempos para mulheres e crianças? Ed. FIOCRUZ, 2005.

GARCIA, R. Embrião usado para terapias não vai morrer, diz Nobel. Folha de São Paulo online, São Paulo, 10 mar. 2008. Disponível em http://www1.folha.uol.com.br/folha/ ciencia/ult306u380274.shtml. Acesso em: 15 jul. 2008.

GARCIA DOS SANTOS, L. Politizar as Novas Tecnologias (impacto sociotécnico da informação). São Paulo: Editora 34, 2003.

\section{GUESSER, A. H. Software livre e} controvérsias tecnocientíficas: uma análise sociotécnica no Brasil e em Portugal. Dissertação de Mestrado defendida no Programa de Pós-Graduação em Sociologia Política, UFSC, 2005.

HARAWAY, D. Manifesto ciborgue: ciência, tecnologia e feminismo-socialista no final do século XX. In: Silva, T. T. da (Org.). Antropologia do Ciborgue - as vertigens do pós-humano. Belo Horizonte: Autêntica, 2000 .

REVISTA ISTO É. A Ciência Perde Mais Uma. Revista Isto É, 12 mar. 2008. Disponível em http://64.233.169.104/search?q=cache:GvmM5-06AEJ:www.terra.com.br/istoe/ edicoes/2001/artigo74220-1.htm+\%22O+adi amento + da + decis $\% \mathrm{C} 3 \% \mathrm{~A} 3 \mathrm{o}+$ sobre $+\mathrm{a}+$ libera $\% \mathrm{C} 3 \% \mathrm{~A} 7 \% \mathrm{C} 3 \% \mathrm{~A} 3 \mathrm{o}+$ das + pesquisas + com $+\mathrm{c}$ $\% \mathrm{C} 3 \% \mathrm{~A} 91$ lulastronco+embrion $\% \mathrm{C} 3 \% \mathrm{~A} 1$ rias + no+Brasil+retardar $\% \mathrm{C} 3 \% \mathrm{~A} 1+$ ainda + mais + o+desenvolvimento + no $+\mathrm{Pa} \% \mathrm{C} 3 \% \mathrm{ADs}+\mathrm{de}+\mathrm{u}$ $\mathrm{ma}+\% \mathrm{C} 3 \% \mathrm{~A} 1 \mathrm{rea}+\mathrm{da}+\mathrm{ci} \% \mathrm{C} 3 \% \mathrm{AAncia}+$ que, + no + mundo, + encontra-se + em + franca + eferve sc\%C3\%AAncia $\% 22 \& \mathrm{hl}=$ pt-BR\&ct=clnk\&c- $\mathrm{d}=1 \& \mathrm{gl}=\mathrm{br}$

KOTTOW, M. A Bioética do Início da Vida. In Schramm, F. R. \& Braz, M. (Org.). Bioética e Saúde: Novos tempos para mulheres e crianças? Ed. FIOCRUZ, 2005.

JB ONLINE. STF decide amanhã se país deve utilizar células-tronco em pesquisas. Jornal JB online, 04 mar. 2008. Disponível em http:/quest1.jb.com.br/extra/2008/03/04/ e040316009.html. Acesso em: 09 jun. 2008.

Pesquisas com células-tronco não são aborto', diz advogado. Jornal JB online, 05 mar. 2008. Disponível em http://quest1.jb.com.br/extra/2008/03/05/ e050316621.html. Acesso em: 09 jun. 2008.

LATOUR, B. Jamais fomos modernos. São Paulo: Editora 34, 1994.

Ciência em ação: como seguir cientistas e engenheiros sociedade afora. São Paulo: Editora UNESP, 2000.

A Esperança de Pandora.

Bauru, SP: EDUSC, 2001.

LOPES, J. F.; NERY, H. R. O Voto Assombroso do Ministro Ayres Britto. Revista Jurídica Consulex. Ano XII, n. 269, Brasília: Consulex, 2008.

NOBRE, J. C. A. \& PEDRO, R. M. L. R. Dos sólidos às redes: Algumas questões sobre a produção de conhecimento na atualidade. in Série Documenta/Universidade Federal do Rio de Janeiro. Pós-graduação em Psicossociologia de Comunidades e Ecologia Social, ano III, n 12-13, - p. 43 -56, 20012002 .

Redes de Bioética e Biotecnologias da Reprodução: Controvérsias teóricas e metodológicas. Anais do $\mathbf{X X X}^{\mathbf{0}}$ Encontro anual da ANPOCS, CD-ROM, 2006.

MOSER, A. Entrevista concedida a JB Online. JB Online, 02 dez. 2007. Disponível em http://quest1.jb.com.br/extra/2007/12/02/ e02124906.html. Acesso em: 15 jul. 2008. 
RABINOW, P. Antropologia da Razão. Rio de Janeiro: Relume Dumará, 2002.

RODRIGUES, F. C. P. Células-tronco embrionárias e o STF. Revista Jurídica Consulex. Ano XII, n. 269, Brasília: Consulex, 2008.

SEGRE, M. Ética e Uso de Células-Tronco. Revista Jurídica Consulex. Ano XII, n. 269, Brasília: Consulex, 2008.

VELHO, L. \& VELHO, P. A controvérsia sobre o uso de alimentação alternativa no combate à subnutrição no Brasil. História, Ciências, Saúde - Manguinhos, vol. 9(1), p. 125-157, 2002.

Endereço para Correspondência:

Prof Júlio Cesar de Almeida Nobre Curso de Serviço Social jcanobre@globo.com

Centro Universitário de Volta Redonda Campus Três Poços

Av. Paulo Erlei Alves Abrantes, $n^{\circ}$ 1325,

Três Poços - Volta Redonda / RJ

CEP: 27240-560

Informações bibliográficas:

Conforme a NBR 6023:2002 da Associação Brasileira de Normas Técnicas (ABNT), este texto científico publicado em periódico eletrônico deve ser citado da seguinte forma: NOBRE, J. C. A.; VALE, M. O.; ANDRADE, E. F.; RIBEIRO, R. L.. O Conceito de "Vida Humana" e as Novas Biotecnologias da Reprodução: analisando uma rede de controvérsias, Volta Redonda, ano III, n. 8, dezembro. 2008. Disponível em: <http://www.unifoa.edu.br/pesquisa/caderno/edição/08/37.pdf > 